\title{
Transformation with Bacteriocin Factors in Staphylococci
}

\author{
By SUJATA G. DASTIDAR \\ Division of Microbiology, Jadavpur University, Calcutta-32, India \\ AND SMITA MITRA, S. N. SARKAR AND A. N. CHAKRABARTY \\ Division of Microbiology, Indian Institute of Experimental Medicine, \\ Calcutta-32, India
}

(Received 2 January 1974; revised 19 April 1974)

\begin{abstract}
SUMMARY
Transfer of bacteriocin factors from bacteriocinogenic to other staphylococci was observed at high frequency on the basis of paradoxical inhibition (p.i.) on two media (BTM and MPI). Colonies of non-bacteriocinogenic sensitive bacteria from the central growth of p.i. showed acquisition of bacteriocinogeny and bacteriocin resistance at high frequencies which was not lost in the course of $18 \mathrm{~h}$. Acquired bacteriocinogeny was a stable character and had an overall frequency of $\mathrm{IO}^{-2}$ to $\mathrm{IO}^{-3}$ among different recipient populations. Conjugation, transduction and transfection processes could be excluded, and the gene transfer process was considered to be transformation with plasmid DNA.
\end{abstract}

\section{INTRODUCTION}

A central region of growth has been observed within the zone of inhibition produced by bacteriocinogenic bacteria among Escherichia coli (Fredericq, 1948), Shigella sonnei (Abbott \& Shannon, 1958), Pseudomonas aeruginosa (Wahba, 1963), Vibrio cholerae (Chakrabarty, Adhya, Basu \& Dastidar, 1970) and among different members of Shigella, Salmonella, Escherichia, Proteus, Vibrio and Alcaligenes spp. (Chakrabarty \& Dastidar, 1974). Chakrabarty, Adhya, Basu \& Dastidar (1970) called the phenomenon paradoxical inhibition (p.i.) and Chakrabarty \& Dastidar (1974) demonstrated that transfer of bacteriocinogeny from the primary to the secondary bacteria which constituted the central growth took place at high frequency through a process of plasmid-mediated genetic transformation. Bacteriocinogeny is also known among staphylococci (Parker, Tomlinson \& Williams, 1955; Barrow, 1963; Fink \& Ortel, 1969; Gagliano \& Hinsdill, I970; Jetten, Vogels \& de Windt, 1972). We report on transfer of bacteriocinogeny among staphylococci observed in the p.i. system.

\section{METHODS}

Bacteria. The strains used are described in Table I. The stock cultures were maintained as described by Chakrabarty \& Dastidar (1974).

Tests for p.i. and transformation. All the media and methods used are essentially those of Chakrabarty \& Dastidar (1974); only the modifications are described here. Bacteriocinogeny was studied on (i) Tryptone soya broth (Oxoid, CMr29) $2 \%$, agar (Oxoid, No. 3, $\mathrm{L}_{13}$ ) I $2 \%$, plus $5 \%$ sterile defibrinated sheep blood, and (ii) the bacteriocin typing medium (BTM, see 
Table I. Cultures

\begin{tabular}{|c|c|c|c|c|}
\hline Description* & Group $\dagger$ & Subgroup $\dagger$ & $\begin{array}{l}\text { No. of } \\
\text { strains }\end{array}$ & Source \\
\hline $\begin{array}{l}\text { Staphylococcus aureus } 6571 \ddagger^{(+)} \text {, } \\
8530 \ddagger, 8531 \ddagger, 8532 \ddagger\end{array}$ & $\stackrel{\mathrm{I}}{\text { (Staphylococcus) }}$ & I & 4 & S. P. Lapage, London \\
\hline $\begin{array}{l}\text { S. aureus } \mathrm{SAI}, \mathrm{SA} 8^{(+)}, \mathrm{SAI}^{(+)} \text {, } \\
\text { SA22 }\end{array}$ & $I$ & 1 & 4 & $\begin{array}{l}\text { Choudhuri \& Chakrabarty } \\
\text { (1970) }\end{array}$ \\
\hline S. aureus $\mathrm{B} 8, \mathrm{B9}, \mathrm{B} 43, \mathrm{~B} 45^{(+)}$ & I & I & 4 & N. Gupta, Calcutta, India \\
\hline $\begin{array}{l}\text { S. aureus ML 32, ML 34, ML42, } \\
\text { ML62, etc. }\end{array}$ & I & I & $4,7^{(+)}, 13$ & $\begin{array}{l}\text { M. R. Lahiri, Calcutta, } \\
\text { India }\end{array}$ \\
\hline S. aureus others & I & I & $11^{(+)}, 15$ & Authors \\
\hline S. saprophyticus 28 & I & II & I & N. W. Preston, Manchester \\
\hline $\begin{array}{l}\text { S. saprophyticus ws2, ws9, vSI4, } \\
\text { etc. }\end{array}$ & I & II & 3, II & $\begin{array}{l}\text { Choudhuri \& Chakrabarty } \\
\text { (I970) }\end{array}$ \\
\hline S. saprophyticus B2, B4, B12, B24 & $I$ & II & 4 & N. Gupta, Calcutta, India \\
\hline $\begin{array}{l}\text { S. saprophyticus ML6 } 6^{(+)}, \text {MLI2, } \\
\text { ML47, MLI23 }\end{array}$ & I & II & 4 & $\begin{array}{l}\text { M. R. Lahiri, Calcutta, } \\
\text { India }\end{array}$ \\
\hline \multirow{2}{*}{$\begin{array}{l}\text { S. saprophyticus, etc. } \\
\text { Staphylococcus spp. }\end{array}$} & I & II & $8^{(+)}, 10$ & Authors \\
\hline & I & IV-VI & I0 & $\begin{array}{l}\text { M. R. Lahiri, Calcutta, } \\
\text { India }\end{array}$ \\
\hline S. afermentans 60 & $\stackrel{2}{2}$ & 7 & $\mathbf{I}$ & N. W. Preston, Manchester \\
\hline \multirow[t]{2}{*}{ S. afermentans, etc. } & 2 & 7 & 3 & Authors \\
\hline & iocinogenic & ns. & & \\
\hline
\end{tabular}

Chakrabarty et al. 1970) consisting of the above medium with $0.05 \%$ tri-sodium citrate. The medium for paradoxical inhibition (MPI) for Staphylococcus was casein hydrolysateyeast extract agar with $0.008 \%$ sodium dodecyl sulphate (SDS) and $0.001 \%$ EDTA, pH 7.4 to 7.5 . In the basic technique for demonstration of bacteriocinogeny and p.i., incubation of primary bacteria was for $72 \mathrm{~h}$ and overnight refrigeration of BTM plates was omitted. For producing a continuous band of central growth (as in acquisition and frequency tests, see below) $0.1 \mathrm{ml}$ of a $\mathrm{I}: \mathrm{I}$ o dilution of the culture was spread uniformly over the surface of the medium. In assay of bacteriocins in the extracted fluids, the method of Gagliano \& Hinsdill (1970) was followed. In the tests for acquisition of bacteriocinogeny, growth samples of different portions of the secondary inoculum were obtained 6 and $18 \mathrm{~h}$ after application. In tests for p.i. on a cell-free surface, both BTM and MPI media were used, and other procedures remained unchanged. The tests for extracellular mediator of p.i. were modified by lowering the final concentration of SDS to $0.001 \%$ in the shake culture fluid, keeping other procedures the same. In 'curing' tests, SDS was tested within the range 0.005 to $0.03 \%$ at intervals of $0.005 \%$, for determination of its minimum inhibitory concentration and 'curing' effects on different strains of staphylococci.

\section{RESULTS}

\section{Bacteriocinogeny among staphylococci on BTM}

Preliminary studies on bacteriocinogeny among staphylococci were made on 64 strains of group I, comprising 30 Staphylococcus aureus (subgroup I), 24 S. saprophyticus (subgroup II) and ten other strains (from other subgroups) (Baird-Parker, 1965). These strains were 


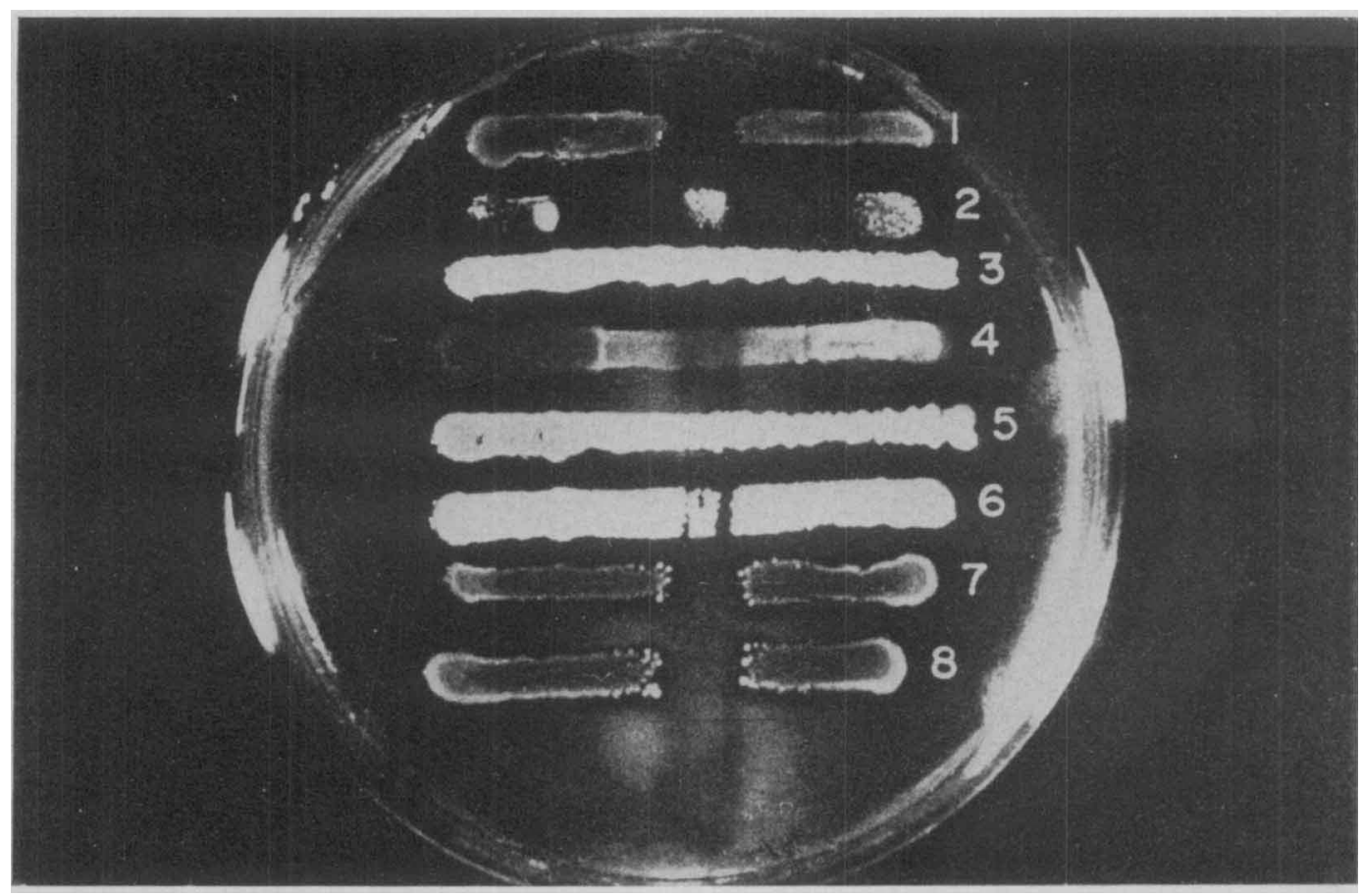

Fig. I. The inhibition pattern of bacteriocinogenic strain Staphylococcus aureus ML34 on BTM. The indicator bacteria, in the order I to 8, are: $S$. saprophyticus vsI4 and ML6, $S$. aureus B43, SA22 and $845, S$. saprophyticus MLI23 and WS2, and $S$. aureus sAI. Numbers I, 7 and 8 show inhibition $(+++$, up to $9 \mathrm{~mm}) ; 3$ and 5 are resistant $(-)$, while 4 shows markedly reduced growth over the central area $( \pm)$. Two plaque-like clearings on the left peripheral growth of no. 5 suggest phage action, and appear to have been derived from the indicator bacterium itself as its streaking was started from the left. Numbers 2 and 6 show p.i. with all the three morphological components, but differ from each other with respect to the width of their inhibition zones $(++++$ or $>9 \mathrm{~mm}$, and ++ or up to $6 \mathrm{~mm}$, respectively), the density of the central growths (more in no. 6 ) and their symmetry on two sides of the midline (fusion is complete in 2 but incomplete in the upper portion of 6).

divided into eight batches, members of which were tested against each other as primary and secondary bacteria; 21 producer and 29 indicator bacteria were thereby detected. Eight of the indicator strains were finally selected on the basis of maximum distinguishing capacity and stability of their reactions. Incidence of bacteriocinogeny among 1 I 7 strains of staphylococci (Table I) was $38(32.5 \%)$ on BTM without citrate and $85(72 \cdot 7 \%)$ on complete BTM, as detected by the indicator set. The reactions of different indicator bacteria are shown in Fig. 1 .

\section{Paradoxical inhibition among staphylococci on BTM and MPI}

Paradoxical inhibition was commonly encountered on BTM without citrate. The incidence of p.i. with eight indicator staphylococci tested against 85 bacteriocinogenic strains (Table I) used as primary strains on complete BTM was $39,33,24,18$, I I, 3, o and o. Studies on the effects of different combinations of SDS, EDTA, tri-sodium citrate and $\mathrm{pH}$ in various concentrations in casein hydrolysate-yeast extract agar medium on p.i. showed that SDS

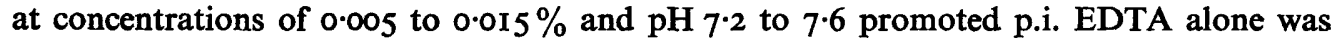
ineffective, but at concentrations between 0.0005 and $0.0015 \%$ it enhanced the effects of SDS. Tri-sodium citrate did not have any effects. When ten different bacteriocinogenic 


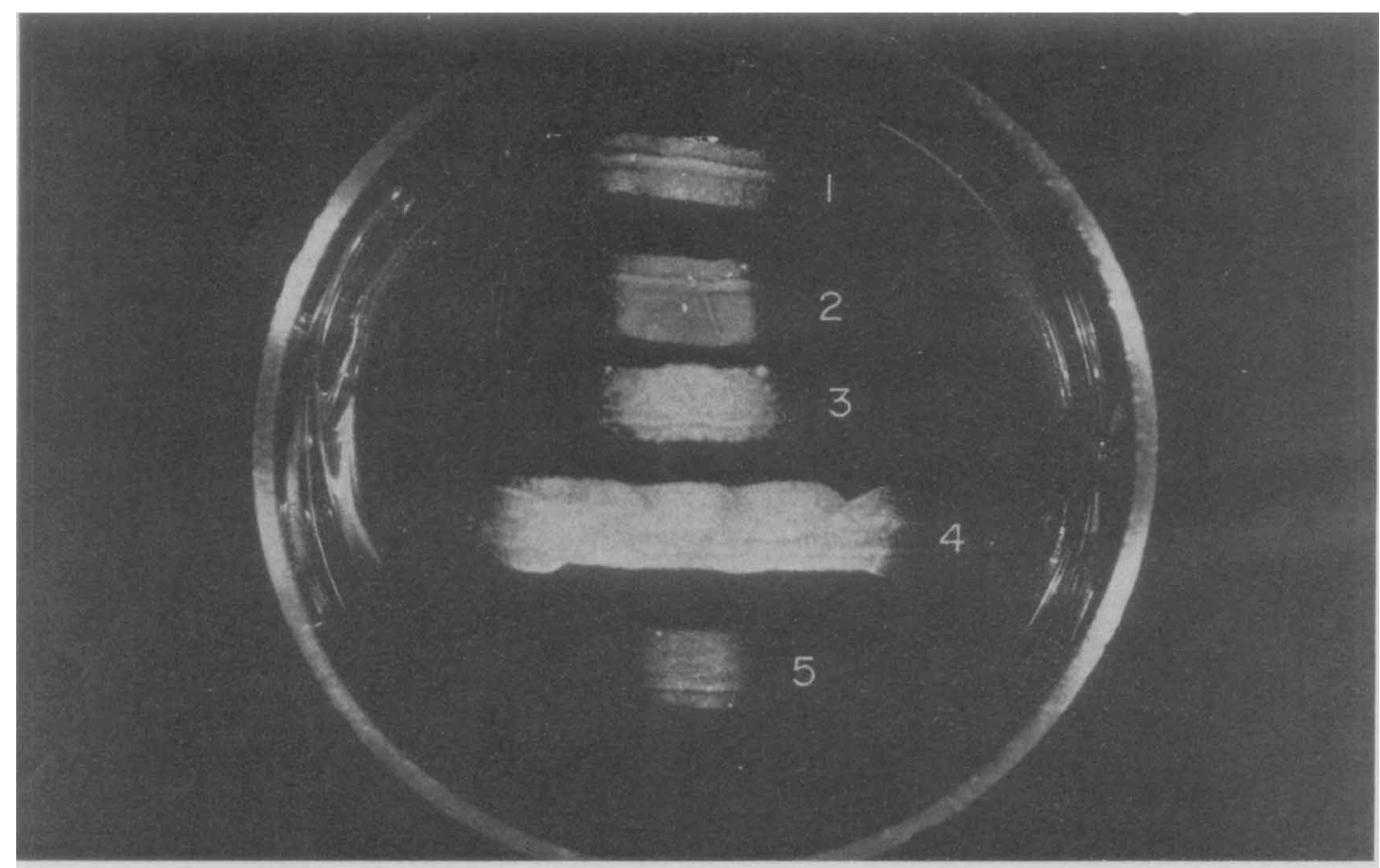

Fig. 2. Paradoxical inhibition produced by Staphylococcus aureus ML34 on MPI medium. The secondary bacteria, in the order I to 5, are: S. saprophyticus MLI23, S. aureus SAI and SA8, and $S$. saprophyticus vsI4 and ws2. Only central growths, of different widths, are present.

staphylococci were tested against these indicators on MPI, p.i. was observed between all the reacting pairs in at least one of the three incubation schedules of the primary inocula, e.g. 54, 64 and $72 \mathrm{~h}$. Certain indicators, e.g. Staphylococcus saprophyticus ws2, ML6 and ML123, exhibited higher frequency of p.i. compared with others (cf. incidence of p.i. on BTM). The frequency of p.i. between representative staphylococcus and micrococcus strains belonging to different subgroups of Baird-Parker (1965), when tested against each other on MPI, was found to be very high. Only bacteriocinogenic bacteria used as primary inocula on MPI produced p.i. with its own, other bacteriocinogenic and non-bacteriocinogenic secondary inocula. When the primary and secondary inocula belonged to different cultures, central growths of p.i. identified as described in Table I were found to belong to the secondary inocula. Exposure to chloroform vapour for $2 \mathrm{~h}$ killed all the staphylococcal cultures examined: even after prolonged incubation, tests in which secondary inoculations were omitted or done as parallel streaks leaving areas of uninoculated medium did not yield growth either in the medium or within the uninoculated zones.

Morphology of p.i. on BTM and MPI. These were as described elsewhere (Chakrabarty \& Dastidar, I974; see also Figs. I and 2).

\section{Assay of bacteriocins}

The bacteriocin titres on BTM were highest in the central zone, followed by the zones of inhibition; no bacteriocin activity could be detected in the peripheral zones. On MPI, in contrast, the titres in the different zones were nearly equal. Replicate plates used as controls showed p.i. with the indicator strains used for assay. 
Table 2. Bacteriocin inhibition patterns of recipient colonies of Staphylococcus aureus SA 8

Colonies from central growth of p.i., selected at random but in approximately equal numbers from BTM and MPI, were tested for bacteriocinogeny as primary bacteria. Forty of 47 colonies acquired bacteriocinogeny.

\begin{tabular}{|c|c|c|c|c|c|c|}
\hline \multirow[b]{3}{*}{ Indicators } & \multicolumn{6}{|c|}{ Inhibition patterns } \\
\hline & \multirow{2}{*}{$\begin{array}{l}\text { Primary } \\
\text { S. aureus } \\
\text { ML34 }\end{array}$} & \multirow{2}{*}{$\begin{array}{c}\text { Secondary } \\
\text { S. aureus } \\
\text { SA8 }\end{array}$} & \multicolumn{4}{|c|}{ Recipient colonies (SA8) } \\
\hline & & & $\mathbf{I}$ & 2 & 3 & 4 \\
\hline S. saprophyticus VsI4 & $+t+$ & - & $++t$ & - & - & - \\
\hline S. saprophyticus ML6 & $\mathrm{PI}++++$ & - & $\mathrm{PI}++$ & $++t$ & +++ & $\mathbf{P I}++$ \\
\hline S. aureus $\mathrm{B} 43$ & - & - & - & - & - & - \\
\hline S. aureus SA22 & \pm & - & - & - & - & - \\
\hline S. aureus B45 & $=$ & - & - & - & - & - \\
\hline S. saprophyticus ML123 & $\mathbf{P I}++$ & - & $\mathbf{P I}++$ & - & - & $\mathbf{P I}++$ \\
\hline S. saprophyticus ws2 & $+t+$ & - & $++t$ & $+t+$ & - & +++ \\
\hline$S$. aureus SAI & +++ & - & + & - & - & - \\
\hline $\begin{array}{l}\text { No. or colonites or each } \\
\text { type }\end{array}$ & (SC) & (SC) & 16 & 13 & 7 & 4 \\
\hline
\end{tabular}

,,,++++++++++ , Width of zones of inhibition, up to $3,6,9$ and $>9 \mathrm{~mm}$ respectively; \pm , markedly reduced growth in the centre; - , resistant; $\mathrm{PI}++, \mathrm{PI}+++$ and $\mathrm{PI}++++$, width of central growth $4 \mathrm{~mm}$ and zones of inhibition up to 6 and 9 and $>9 \mathrm{~mm}$, respectively; SC, stock culture.

\section{Acquistion of bacteriocinogeny}

Paradoxical inhibition occurred when the non-bacteriocinogenic strain $S$. aureus SA8 was inoculated as secondary culture against the bacteriocinogenic strain $S$. aureus ML34. The results showed that only colonies originating from the central growth of p.i. on BTM and MPI acquired bacteriocinogeny, while those belonging to other areas did not. The frequency of acquisition was high in all the tests and did not decline in the course of $18 \mathrm{~h}$. Bacteriocinogeny, once acquired, was remarkably stable, as evidenced by tests repeated at intervals for a year; in addition, these colonies could produce p.i. as primary bacteria with members of the indicator set. The inhibitory patterns of some randomly selected bacteriocinogenic colonies are given in Table 2. Additional studies with $S$. aureus ML34 and ML32 as primary and $S$. saprophyticus ML6 and $S$. aureus SAI2 as secondary bacteria respectively produced similar results; of 40 colonies of $S$. saprophyticus ML 6 tested, 36 had acquired bacteriocinogeny and were distributed among four different inhibition patterns in the proportions $36,28,22$ and $14 \%$; similarly, of 42 colonies of $S$. aureus SAI 2 tested, 39 were bacteriocinogenic and distributed into four different patterns at 44, 26, 20 and $10 \%$. Control experiments, with $S$. aureus SA8 and $S$. saprophyticus ML6 as primary bacteria against these same strains as secondary bacteria on BTM and MPI, failed to reveal acquired bacteriocinogeny.

Frequency of acquisition of bacteriocinogeny. Using $S$. aureus ML34 as primary inoculum, the frequencies for $S$. aureus SA8 and $S$. saprophyticus ML6 (secondary bacteria) on MPI were $2 \cdot 2 \times 10^{-2}$ and $1.6 \times 10^{-3}$ respectively.

\section{Paradoxical inhibition on cell-free surface}

Primary bacteria were Staphylococcus aureus ML32 and ML34; secondary bacteria were $S$. aureus SAI 2 and SA8, and $S$. saprophyticus ML6, WS2 and MLI 23. Inoculations of secondary bacteria on reverse and agar overlaid surfaces on BTM and MPI produced p.i. similar to that seen on the control plates where the primary and secondary bacteria were on the same surface. Colonies from the central area of growth of p.i. belonging to $S$. aureus SAI2 and SA8 against $S$. aureus ML32 and ML34 respectively showed acquisition of bacteriocinogeny. 


\section{Paradoxical inhibition with DNA preparation}

The inclusion of DNA prepared from the bacteriocinogenic strain $S$. aureus ML34 in gutters and inoculation of secondary bacteria as in the preceding test, using the basic technique described in Methods, similarly produced p.i. The colonies derived from the central growths of p.i. of $S$. aureus SAI2 and SA8 (non-bacteriocinogenic) against $S$. aureus ML34 showed acquired bacteriocinogeny. None of the non-bacteriocinogenic indicator bacteria or their DNA preparations produced p.i., nor did media containing no DNA preparations. DNase treatment of the DNA preparations abolished p.i. for all the indicator bacteria, while RNase treatment did not.

\section{Effects of SDS on growth and bacteriocinogeny}

Of 15 different staphylococcal strains tested, the number of strains that grew on 0.005 , $0.01,0.015,0.02,0.025$ and $0.03 \%$ SDS in liquid and solid media respectively were 15,13 , $7,4,1$ and 0 , and $13,10,5,1,0$ and 0 . The results showed that the 'curing' doses of SDS $(0.005$ to $0.015 \%)$ were lower than the inhibitory ones and could entirely or partly 'cure' these cultures of bacteriocinogeny.

The behaviour of light (secondary) and heavy (primary) inocula on media containing different combinations of SDS and bacteriocins were studied with respect to five bacteriocinogenic strains. On BTM containing homologous bacteriocin, secondary light and heavy inoculations of these bacteria yielded good growth, except in one instance where p.i. occurred. Fresh MPI gave similar results for all the bacteria tested. However, in the presence of preformed bacteriocins resulting from a heavy primary inoculum, secondary heavy inocula of the homologous bacteria showed markedly reduced growth except over the central area where it was luxuriant, while secondary light inocula of homologous and heterologous bacteria produced p.i. Light primary inocula did not inhibit any of these cultures, irrespective of the type of secondary inoculum.

\section{DISCUSSION}

Two sorts of bacteriocin resistance were seen in the secondary inocula on plates: (i) that due to resistant colonies situated within the zones of inhibition (occurring in small numbers on BTM and rarely on MPI); as these colonies did not acquire bacteriocinogeny, they were considered to be mutants; (ii) that due to the central growth. The colonies constituting the latter (on BTM and MPI) grew in the presence of comparatively high concentration of bacteriocin and showed both bacteriocin 'resistance' and acquired bacteriocinogeny. Paradoxical inhibition and acquisition of bacteriocinogeny by these colonies depended on the presence of bacteriocins, on the primary culture being bacteriocinogenic, or on the free DNA from such cultures (as these were sensitive to DNase and resistant to RNase), but did not depend on cell contact. As in the previous study (Chakrabarty \& Dastidar, 1974), the transfer process described here appears to be genetic transformation and the central growth appears to be due to transformant selection in situ by the bacteriocins.

The inhibition patterns of the recipient colonies of $S$. aureus SA8 belonged to four different types, only one of which (inhibition pattern I) resembled that of the primary, $S$. aureus ML34 (Table 2). These findings suggest that the minimum number of transferred bacteriocin factors could be two, and transfer of such factors in different combinations probably occurs among staphylococci (cf. Chakrabarty \& Dastidar, 1974). This coupled with a host-modified phenotypic expression (the inhibition pattern $\mathrm{I}$ of the transformant, $S$. aureus $\mathrm{SA} 8$, appeared 
to be weaker than that of the donor) may account for different bacteriocin types among the transformants.

An evaluation of the role of tri-sodium citrate suggests that although it could stimulate bacteriocin production and protect DNA liberated in the medium (see Results and Hotchkiss, 1957), it is obligatory for neither bacteriocinogeny nor for p.i., and therefore does not wholly account for p.i. and transformation on BTM. The role of SDS in such processes, and in the mechanism of release of transforming DNA, had been discussed under similar situations (Chakrabarty \& Dastidar, 1974). SDS at the concentration (0.008\%) used in MPI is unlikely to release DNA by lysing primary bacteria, but it could probably do so (i) by increasing the spontaneous breakdown of bacteria (Elek, 1959) and (ii) by releasing intracellular macromolecules as a result of its selective action on the cell membrane (Sonstein \& Baldwin, 1972; Woldringh \& van Iterson, 1972). Its 'plasmid curing' role also could be of significance. Our studies on SDS showed that it could eliminate the determinants of bacteriocinogeny from different wild and transformant (recipient) cultures at high frequency. The studies of Gagliano \& Hinsdill (1969) also suggest that the bacteriocin factors among staphylococci are plasmid-linked and could be 'cured'. As in the earlier studies, the central growth of p.i. described here could be due to acquisition by cells of the secondary inoculum through the transformation process of plasmid DNA of the donor, released either spontaneously or as a result of the 'curing' effects of SDS.

It is evident that the transfer of bacteriocin factors among staphylococci is like that observed among enterobacteria, Vibrio, and Alcaligenes spp. (Chakrabarty \& Dastidar, 1974). However, the acquisition process among the former appears to be more stable on MPI in comparison with that for other bacteria studied (Chakrabarty \& Dastidar, 1974) because the acquired bacteriocin factors were substantially retained for $18 \mathrm{~h}$ or more. The causes for such a difference are not understood.

Genetic transformation among staphylococci was suggested by the works of Pakula, Hulanicka \& Waczak (1958), Imshenetskii, Perova, Zaitseva \& Belozerskii (1959), Lambina (196I), Komarov (1962), Dobrzanski, Osowiecki \& Jagielski (1968), Smirnova, Gubenko \& Rybakova (1969) and Nomura et al. (197I), although Elek (1959) and Spizzizen, Reilly \& Evans (I966) considered this to be improbable. Lindberg \& Novick (I973) demonstrated transformation with plasmid DNA in one strain of staphylococcus. Our present and earlier investigations (Chakrabarty \& Dastidar, 1974) show that plasmid-mediated genetic transformation is a widely prevalent phenomenon among staphylococci and different groups of Gram-negative bacteria. Further studies may throw more light on this potentially important aspect of bacterial genetics.

The authors' grateful thanks are due to the Vice-Chancellor, Jadavpur University, and the Director, Indian Institute of Experimental Medicine, Calcutta, India, for providing the facilities to carry out this work, and to Mr K. N. Maitra and Mr I. Guha Thakurta for their technical assistance.

\section{REFERENCES}

Aввott, J. D. \& Shannon, R. (1958). A method of typing of Shigella sonnei using colicine production as a marker. Journal of Clinical Pathology Ir, 71-77.

BAIRD-PARKER, A. C. (1965). The classification of staphylococci and micrococci from world-wide sources. Journal of General Microbiology 38, 363-387.

BARRow, G. J. (1963). Microbial antagonism by Staphylococcus aureus. Journal of General Microbiology 3I, 47I-481.

Chakrabarty, A. N., Adhya, S., Basu, J. \& Dastidar, S. G. (1970). Bacteriocin typing of Vibrio cholerae. Infection and Immunity $\mathrm{x}, 293-299$. 
Chakrabarty, A. N. \& Dastidar, S. G. (1974). Paradoxical inhibition among bacteria. Characterization of the phenomenon and nature of the genetic process. Journal of General Microbiology 80, 339-361.

Choudhurr, K. K. \& ChaKrabarTy, A. N. (1970). Relationship of staphylococcal toxins and enzymes with serological and phage types. Journal of Clinical Pathology 23, 370-372.

DobrZANSKI, W. T., OsowIECKI, H. \& JAGIELSKI, M. A. (I968). Observation on intergeneric transformation between Staphylococci and Streptococci. Journal of General Microbiology 53, 187-196.

ELEK, S. D. (1959). Staphylococcus pyogenes and Its Relation to Disease, p. 15I. Edinburgh: Livingstone.

FinK, H. \& ORTEL, S. (1969). Studies on Staphylococcus strains, origin, lysis spectrum and sensitivity to antibiotics. Zentralblatt für Bakteriologie, Parasitenkunde, Infektionskrankheiten und Hygiene (Abteilung I) 21r, 39-47.

FreDERICQ, P. (1948). Actions antibiotiques réciproques chez les Enterobacteriaceae. Revue belge de pathologie et de médicine expérimentale $19, \mathrm{~S} 4,59-165$.

GaGliano, U. \& Hinsdill, R. (1970). Characterization of Staphylococcus aureus bacteriocin. Journal of Bacteriology 104, $117-125$.

Hotchkiss, R. D. (1957). Methods in Enzymology 3, 692-696. New York: Academic Press.

Imshenetskit, A. A., Perova, K. Z., ZaitseVa, T. A. \& Belozerskit, A. N. (1959). Transmission of streptomycin resistance in staphylococci by means of DNA. Microbiology 28, 175-1 78.

Jetten, A. M., Vogels, G. D. \& DE Windt, F. (1972). Production and purification of a Staphylococcus epidermidis bacteriocin. Journal of Bacteriology 112, 235-242.

Komarov, P. V. (1962). A study of some quantitative indicators of DNA-mediated transmission of streptomycin resistance in staphylococci. Microbiology 31, 371-374.

LAMBINA, V. A. (1961). Induction in staphylococci of resistance to streptomycin, rivanol, and copper by cell-free extracts. Microbiology 30, 53-59.

LINDBERG, M. \& Novick, R. P. (1973). Plasmid-specific transformation in Staphylococcus aureus. Journal of Bacteriology I15, I39-145.

Nomura, H., Udou, T., Yoshida, K., Ichikawa, Y., NaIto, Y. \& Smith, M. R. (197I). Induction of hemolysin synthesis by transformation in Staphylococcus aureus. Journal of Bacteriology 105, 673-675.

Pakula, R., Hulanicka, E. \& Waczak, W. (1958). Transformation reactions between streptococci, pneumococci and staphylococci. Bulletin de l'Académie polonaise des sciences (Classe II) 6, 325-328.

Parker, M. T., Tomlinson, A. J. H. \& Williams, R. E. O. (1955). Impetigo contagiosa. The association of certain types of Staphylococcus laureus and Streptococcus pyogenes with superficial skin infections. Journal of Hygiene 53, 458-473.

Shaw, C., Strrt, J. M. \& CowaN, S. T. (195I). Staphylococci and their classification. Journal of General Microbiology 5, 1010-1023.

Smirnova, V. I., Gubenko, T. L. \& RYbakova, T. M. (1969). Transformation of resistance to streptomycin in Staphylococcus. Mikrobiologichniyi Zhurnal 31, 233-236.

Sonstein, S. A. \& BaldwIN, J. N. (1972). Nature of elimination of penicillinase plasmid from Staphylococcus aureus by surface-active agents. Journal of Bacteriology III, 152-155.

Spizizen, J., Reilly, B. E. \& Evans, A. H. (1966). Microbial transformation and transfection. Annual Review of Microbiology 20, 37I-400.

WAHBA, A. H. (1963). The production and inactivation of pyocines. Journal of Hygiene 6r, 43I-44I.

WOLDRINGH, C. L. \& VAN ITERSON, W. (1972). Effects of treatment with sodium dodecyl sulfate on the ultra structure of Escherichia coli. Journal of Bacteriology $\mathrm{III}, 80 \mathrm{I}-813$. 